Canadian Art Review

\title{
Shaping Reality through the Fictive: Images of Women Spinning in the Northern Renaissance
}

\section{Cordula Grewe}

Volume 19, numéro 1-2, 1992

Art as Propaganda

Art et propagande

URI : https://id.erudit.org/iderudit/1072849ar

DOI : https://doi.org/10.7202/1072849ar

\section{Aller au sommaire du numéro}

\section{Éditeur(s)}

UAAC-AAUC (University Art Association of Canada | Association d'art des universités du Canada)

\section{ISSN}

0315-9906 (imprimé)

1918-4778 (numérique)

\section{Découvrir la revue}

Citer cet article

Grewe, C. (1992). Shaping Reality through the Fictive: Images of Women Spinning in the Northern Renaissance. RACAR : Revue d'art canadienne / Canadian Art Review, 19(1-2), 6-19. https://doi.org/10.7202/1072849ar

\section{Résumé de l'article}

Cet article voudrait montrer comment le motif récurrent des fileuses servait à véhiculer les idées des humanistes et des réformateurs du Nord de l'Europe.

Les artistes utilisaient le thème des fileuses à la fois pour sa valeur symbolique et pour sa grande ancienneté. Le motif leur permettait d'exprimer les nouvelles valeurs morales et les transformations du rôle de la femme. L'usage de la gravure sur bois et de la gravure en taille douce permettait une plus grande diffusion des idées nouvelles qui étaient liées à l'urbanisation des pays transalpins, à une vision plus favorable de la famille et au fait que les femmes étaient exclues du milieu du travail.

Les artistes visaient surtout la classe bourgeoise urbaine qui partageait avec les humanistes et les réformateurs l'idéal de la famille nucléaire. Le motif permettait aux artistes de séparer la « sphère officielle ou mondaine » de l'époux de la « sphère privée ou domestique » de l'épouse. Dans ce contexte, le motif était utilisé de deux façons différentes : dans un contexte domestique il mettait en scène une épouse vertueuse, chaste et obéissante, tandis que hors du domaine familial, il indiquait la prostitution et son comportement immoral. Le thème de la fileuse servait donc à propager un nouveau sens de la famille bourgeoise tout en distinguant très fortement les classes supérieures des classes inférieures où la femme devait travailler pour subvenir aux besoins de la famille.
Tous droits réservés @ UAAC-AAUC (University Art Association of Canada | Association d'art des universités du Canada), 1994
Ce document est protégé par la loi sur le droit d'auteur. L'utilisation des services d'Érudit (y compris la reproduction) est assujettie à sa politique d'utilisation que vous pouvez consulter en ligne.

https://apropos.erudit.org/fr/usagers/politique-dutilisation/ 


\title{
Shaping Reality through the Fictive: Images of Women Spinning in the Northern Renaissance
}

\author{
Cordula Grewe, Alberit-Ludwigs-Universität, Freiburg im Breisgau
}

\begin{abstract}
Résumé

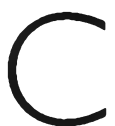

et article voudrait montrer comment le motif récurrent des fileuses servait à véhiculer les idées des humanistes et des réformateurs du Nord de l'Europe.
\end{abstract}

Les artistes utilisaient le thème des fileuses à la fois pour sa valeur symbolique et pour sa grande ancienneté. Le motif leur permettait d'exprimer les nouvelles valeurs morales et les transformations du rôle de la femme. L'usage de la gravure sur bois et de la gravure en taille douce permettait une plus grande diffusion des idées nouvelles qui étaient liées à l'urbanisation des pays transalpins, à une vision plus favorable de la famille et au fait que les femmes étaient exclues du milieu du travail

S tudies dealing with the depiction of women working, and especially of women spinning, have demonstrated that images not only reflect the social conditions in which they originated, but also transmit ideas and concepts

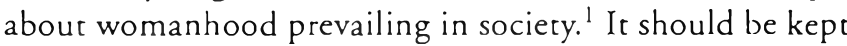
in mind here that such images not only documented women's public roles and personal status, but also anticipated propagated ideals of womanhood that did not necessarily match actual circumstances. In this connection depictions of women spinning are of particular interest since spinning has been the most popular motif of female work among artists. $^{2}$ This popularity appears closely connected to the symbolic meaning that has been attributed to spinning. The metaphor, both literary and artistic, of the virtuous matron spinning and weaving for the family has been a favourite theme since antiquity. Already in Roman times, spinning was mentioned, along with beauty, modesty, piety, frugality and diligence, as a characteristic virtue of the Roman matron. The image of the "eternal spinner of wool" as a symbol for the ideal woman, wife and mother was deeply embedded in the Roman literary and artistic formal repertoire, ${ }^{3}$ and Roman artists used spindles and spinning images to evoke the domestic and private world of the majority of Roman women. ${ }^{4}$ Spinning "was ... a quintessentially female occupation .. alternately honored and oppressed." Setting her observations on Roman women working into the broader context of social and gender stratification, Nathalie Kampen has shown the connections between art, class and gender that existed in Roman antiquity. Applying Kampen's method to Northern Renaissance art, the current analysis aims at defining the function that spinning imagery played in Renaissance culture.
Les artistes visaient surtout la classe bourgeoise urbaine qui partageait avec les humanistes et les réformateurs l'idéal de la famille nucléaire. Le motif permettait aux artistes de séparer la "sphère officielle ou mondaine" de l'époux de la "sphère privée ou domestique" de l'épouse. Dans ce contexte, le motif était utilisé de deux façons différentes: dans un contexte domestique il mettait en scène une épouse vertueuse, chaste et obéissante, tandis que hors du domaine familial, il indiquait la prostitution et son comportement immoral. Le thème de la fileuse servait donc à propager un nouveau sens de la famille bourgeoise tout en distinguant très fortement les classes supérieures des classes inférieures où la femme devait travailler pour subvenir aux besoins de la famille.

Used in negative as well as positive contexts, ${ }^{6}$ Renaissance images of spinning could refer to the two opposites of female conduct: that of the virtuous, chaste and obedient wife and that of the dishonourable woman, the whore. At the end of the Middle Ages, prominent images of spinning reemerged in the arts and blossomed during the Renaissance. Such images were frequently used in engravings and woodcurs dealing with moral issues, and were also introduced into portrait painting at that time. A new interest in the image of spinning women developed because Renaissance artists found its allusions to both metaphorical and literal meaning useful in artistically conceptualizing the emerging moral values and changing social status of women. The background for these cultural and artistic innovations was the basic economic and religious changes that accompanied the transition from the late Middle Ages to an Early Modern society.

The iconographic development of Northern Renaissance representions of women spinning reflected three major transformations; the urbanization of the Northern countries, the shift to a more favourable view of family, and the growing exclusion of women from the work process. An analysis of the art works themselves, and of patrons and potential buyers, reveals that spinning imagery reflected issues of class as well as gender. Artists addressed the "urban middle class" with their subjects ${ }^{7}$ so that one might speak of an "art by burghers for a burgher class." ${ }^{8}$ When, for instance, in the 1480 s a flood of rural poor poured into the cities, " the burgher symbolised the distinction between him and the newcomers in an idiom of virtue and refinement." 10 This striking concern with good morals was reflected in the veritable flood of moralizing texts and illustrations around 
$1500 .{ }^{11}$ The current study focuses on the urban middle class because its images reflect "the distinctly urban character of society" 12 and are inseparably connected with the rise of humanism and the Reformation in the North. The cities constituted an almost ideal breeding-ground for Reformation movements, not only in Germany but also in the Low Countries. The influence of Martin Luther's ideas found its way into these areas before $1520 .^{13}$

This article will show that spinning imagery played an important part in the attempt of humanists and reformers to establish the nuclear family as the new ideal and the preferred social unit. Humanism and the Reformation engendered a profound break with the earlier understanding of marriage. Since Augustine, celibacy had been preferred to marriage, which was regarded as an inferior state of life. In his Summa Theologiae, Thomas of Aquinus revived the Augustinian viewpoint of marriage and pointed out that even conjugal intercourse has to be regarded as principally sinful. ${ }^{14}$ These doctrines fostered misogynist and antimarriage sentiments, which were expressed in such popular German proverbs as "Wem zu wol ist, der neme ein Weib!"15 Under the influence of humanism, however, authors began to champion marriage, children and marital emotional life as important aspects of earthly bliss. ${ }^{16}$ Desiderius Erasmus of Rotterdam explicitly preferred the conjugal state, ${ }^{17}$ and Albrecht von Eyb, the first representative of humanism in Germany, proclaimed that nothing "could be happier and sweeter than the name of father, mother, and children," that is, of a family. ${ }^{18}$ Although Martin Luther did not count marriage among the holy sacraments, he emphasized the divine nature of the marital state. God himself, asserted Luther, had established marriage as a remedy for unchastity. A warm relationship between the couple was also very important for Luther, who advised the husband to love his wife "like his own body." The man's responsibility was to protect and care for his family. ${ }^{19}$ In the reformer's opinion, the suppression of monasteries and nunneries had liberated women from sexual repression and cultural deprivation. ${ }^{20}$

The re-evaluation of marriage enhanced the status of women in their role as virtuous housewife and mother. New emphasis was put on the sort of female education that was thought to improve their qualities as marriage partners. In the trading towns of the Low Countries, a new type of school called "French Schools" developed, offering daughters of the bourgeoisie not only extensive instruction in virtuous behaviour, but also a complete education in commercial subjects to prepare them for their role as merchants' wives. ${ }^{21}$ In the cultivated upper-class households of Flanders, singing, dancing, performing on one or more instruments, and playing chess were considered necessary so- cial skills for women, who are often shown playing keyboard and other instruments in sixteenth century Flemish paintings. ${ }^{22}$ Thus, emphasis in the current analysis is given to the problem of marriage and family, and only marginal attention is paid to the status of unmarried women. Besides women organized in cloisters, beguinages and other religious communities, little is known about unmarried women, ${ }^{23}$ and the specifics of their daily life have not been treated in art. Single women are mainly represented as prostitutes or concubines. One reason for such representations may be the contemporary preference of family and the marital state, which made unmarried women an unwanted phenomenon in both art and society. On the other hand, most single women were poor and belonged to the lower classes, ${ }^{24}$ so that their anonymity may also be the result of their lack of money, status and independence, which prevented them from commissioning art works and representing themselves through them. ${ }^{25}$ Thus, the existence of a large number of poor working women found only an indirect and most antipathetic treatment in images of spinning women.

The difficult financial situation of most unmarried women was also caused by the loss of opportunities for Renaissance women to work and to participate forcefully in the economic process that paralleled the establishment of the new family ideal. Several statistics highlight this shift in work opportunities for women. The number of women that attained citizenship declined drastically during the Renaissance. ${ }^{26}$ Moreover, whereas a high percentage of women - between 15 and 38 percent $^{27}$ - worked in up to 200 different professions in the Middle Ages, ${ }^{28}$ women no longer worked in those trades organized in guilds in the seventeenth century. ${ }^{29}$ In addition, only an extremely small number of women attended the newly founded universities, so that they became excluded from those professions requiring such an education. ${ }^{30}$ Studying was very expensive, and most families did not want to invest money in the education of their daughters, who also needed a dowry in order to marry or to enter a convent. Moreover, fathers probably did not want their daughters partaking in the unrestrained life of students. ${ }^{31}$

In the Middle Ages, the widows of deceased masters usually had the right to continue running their workshops although the scope of their opportunities differed widely. This right was a decisive reason for the large number of women working in all areas of economic life. ${ }^{32}$ Yet, as guilds became interested in reducing the number of working women at the beginning of the Renaissance, they began to restrict even the long-existing rights of widows. Guilds established a time frame for widows operating a workshop, 
usually one or two years, later as little as two months. In the mid-sixteenth century, women could no longer take apprentices and could retain only one or two journeymen, so that widows' workshops and income remained very small. ${ }^{33}$ Sometimes the existence of children, or specifically of sons, was necessary for such permission, as, for example, with the bakers of Hamburg in 1375. Often, cities obliged widows to remarry within a year if they wanted to continue operating their workshops. ${ }^{34}$ Moreover, guilds introduced the prerequisite of being male for guild membership. ${ }^{35}$ The tightening up of guild laws caused a displacement of women to unskilled work of low status, low pay and inferior social status, and reduced their participation in the crafts. This process of exclusion was also possible because women were not able to maintain in law the opportunities they had during the High Middle Ages.

At this point, it should be emphasized that in legal terms the situation of women did not change decisively from the Middle Ages to the Renaissance. Property and inheritance laws show astonishing continuity. In the Middle Ages, legal books such as Eike von Repgow's Sachsenspiegel defined a guardianship for women, called the Munt, either by a male relative, if the woman was unmarried, or by her husband. ${ }^{36}$ . The guardians had to represent the women, who were not allowed to appear in court or to testify in any legal affairs. ${ }^{37}$ According to town marriage laws, the property of married partners was regarded as common property, called Gesamtgut. According to the legal proverb "längs Leib, längs Gut," 38 the wife did not have the right of disposal over either the mutual property or her own, which was the privilege of her husband. Moreover, she was liable for her husband's debts, so that she could not withdraw her own property after the ending of a marriage before all the debts of her spouse were paid. ${ }^{39}$ With the adoption of Roman law at the beginning of the Renaissance, the subordination of the wife was reinforced by the incorporation of the patria potestas, that is the husband's right over his wife. Yet, resistance was displayed against the Roman marriage law regarding the dowry and property of the wife called dos. The dos defined a strict separation of property among married couples and a woman's unrestricted right of disposal of her possessions. Such an arrangement would have brought women a higher independence and was, therefore, rejected in Northern law treatises. ${ }^{40}$ The relatively high percentage of business women was not, therefore, due to a more favourable legal situation, but to a toleration of women's activities, despite the formal restrictions. Cities granted businesswomen legal competence in financial matters because the security of financial commitment was a foundation of commercial activities. Whether married or not, security for busi- nesswomen was not restricted. Male supremacy, however, was guaranteed, as both married and unmarried women relied on the permission of the male Munt to engage in business. ${ }^{41}$ Most probably, women could not establish their attained rights in guild and city laws, since they were excluded from the offices of public law, the Morgensprache and Vorsteheramt. As women steadily lost hold in other commercial occupations and trades, spinning became an important side-occupation, often necessary to support the family. Yet, in order to interpret the artistic imagery of spinning women, it is important to remember that, despite strategies of excluding women from work, a considerable number of women were still involved in economic activities, including widows successfully running inherited workshops. ${ }^{42}$

The loss of women's opportunities for work was related to their re-evaluation as mothers and wives, which included their restriction to the domestic realm. The efforts made to control the economic position of women seem to be part of an attempt to confine the role of women to the home. While the standing of women as mothers and wives was elevated, humanists as well as reformers propagated the attitude that wives should be totally subordinated to the needs and wills of their husbands. Luther insisted that women should not rule. The man was to be the lord of the home unless he were a "Verbum anomalum that is, a fool." 43 According to Erasmus, a good wife is like a mirror that reflects her husband's mood. She has to endure her husband as he is, even despite any injustice, and should win his love through friendliness, kindness and her willingness to be of service. "To be obedient to her husband is the greatest virtue of a woman." 44 In order to assure the leading role of man in marriage, they were strongly advised not to marry a richer wife, as she might want to dominate on the grounds of her property. ${ }^{45}$ Despite the developing status of married women, Renaissance society displayed an intransigent $\mathrm{mi}$ sogyny that found its most belligerent expression in the witch-hunt. This atritude becomes visible in the connection of spinning with the subjects of women's wiles and of the topsy-turvy world. These multifaceted, sometimes opposing views of female existence were reflected in the complex iconography of spinning.

Maerten van Heemskerck depicts a woman spinning in his Portrait of a Lady with Spindle and Distaff (Fig. 1). She keeps the wheel in motion with her right hand, while drawing the raw material - wool or flax - from the distaff with her left hand. The figure's scale is heroic, an impression that is reinforced by the spinner's placement in the extreme foreground, her occupation of the full width of the painting through the wheel, and her outspread arms, all of which contrast with the size of the basket, yarn winder and 
Figure 1. Maerten van Heemskerck, Portrait of a Lady with Spindle and Distaff, ca. 1530. Panel, $105 \times 80,5 \mathrm{~cm}$. Fundacion Coleccion Thyssen-Bornemisza, Madrid.

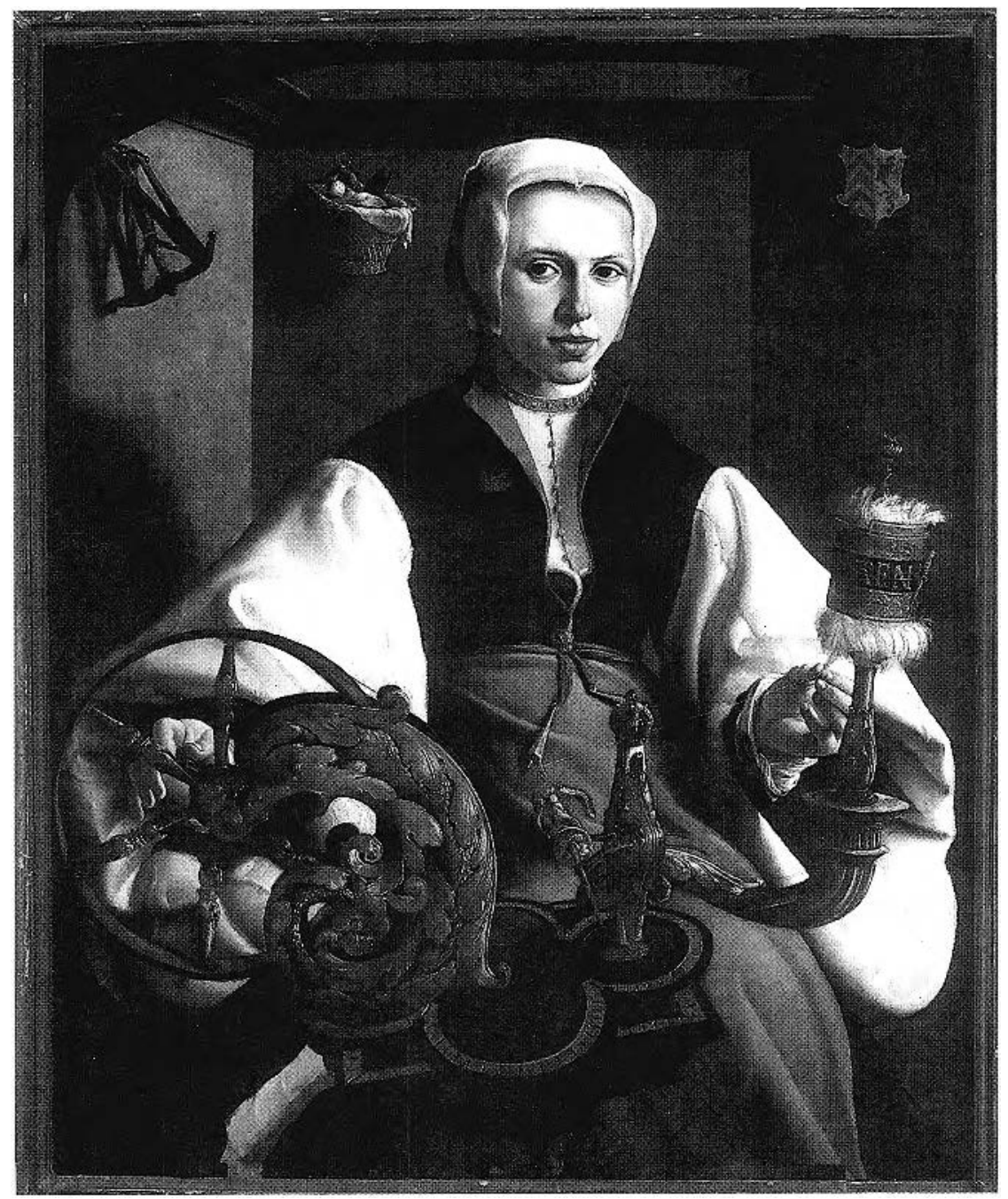

Taking into account the written evidence that spinners who relied on their income for a living were mostly poor, the fanciful spinning wheel, more a valuable artefact than a working tool, indicates that the woman does not spin for money. Instead, spinning is used in a metaphorical way. In a woodcut from Lucas van Leyden's circle, Young Woman at the Spinning Wheel $(1513)^{46}$ the costly costume of the female figure, as well as the embroidered cloth wrapped around the wool on the distaff, recall Heemskerck's composition. The spinner is seated in a ruined, open stone chamber, attentively occupied with her work. A little boy sits on the ground beside her spinning wheel and offers her an apple, a gesture that can be read as a reference to $\sin$ and the Fall. The fanciful scenery and her pointed ignorance of the hostile surroundings suggest a symbolic meaning. Jean Pierre Bryn points out that the symbolic meaning can be traced back to Lemuel's lesson of chastity and temperance and the praise of a good wife (Proverbs 31:13 and 31:19): "She seeketh wool and flax, and worketh willingly with her hands. . . . She layeth her hands to the spindle, and her hands hold the distaff." 47 The tradition of the female spinner illustrating Chapter 31 of Solo-

coat of arms in the background which are tiny and too small in relation to the figure. In addition, the ambiguous, shallow space of the interior presses her figure into the foreground so that she almost seems to protrude from the frame, more part of the onlooker's space than of her own room. Her heroic scale contributes to the grandeur of her presence, which is strengthened by the generous and imposing forms of her costume. Her costume, remarkable in its bold modelling and clear contrasts of black and white, green and red, has precious details such as the fine gold embroidery and the pearl buttons, but it is otherwise simple. The fanciful spinning wheel, with its skilful carvings of acanthus leaves, fluting and finials, and with a dolphin holding the wheel in its mouth, underlines the luxuriant tone of the painting. The demonstration of wealth is counterbalanced by the spare, restrained background and the strong and somewhat heavy features of the woman, both elements that negate any lavish and prodigal lifestyle. mon's proverbs was founded in the French Bible Moralisée, in which it occurred from around 1400. The depictions there belong among the very early reproductions of women spinning at the end of the Middle Ages. ${ }^{48}$

The connection of spinning with virtue, chastity and moral superiority was indeed based on a strong tradition. In the story of the ancient heroine Lucretia, Collatinus' wife proves her virtue by being found spinning instead of celebrating, unlike the other husbands' wives tested. Hendrik Goltzius shows Lucretia in his series of the Story of Lucretia (Fig. 2) among her housemaidens, an icon of the dutiful and trustworthy wife. The five women are involved in all stages of yarn production. The one at the far right sits at the spinning wheel to make the thread, and the one at the far left stretches it on a wool winder, whereas Lucretia herself rolls the finished thread into a ball. The standing figure holds a pair of scissors in her right hand and carries a basket of yarn under her left arm. The maid in the back- 


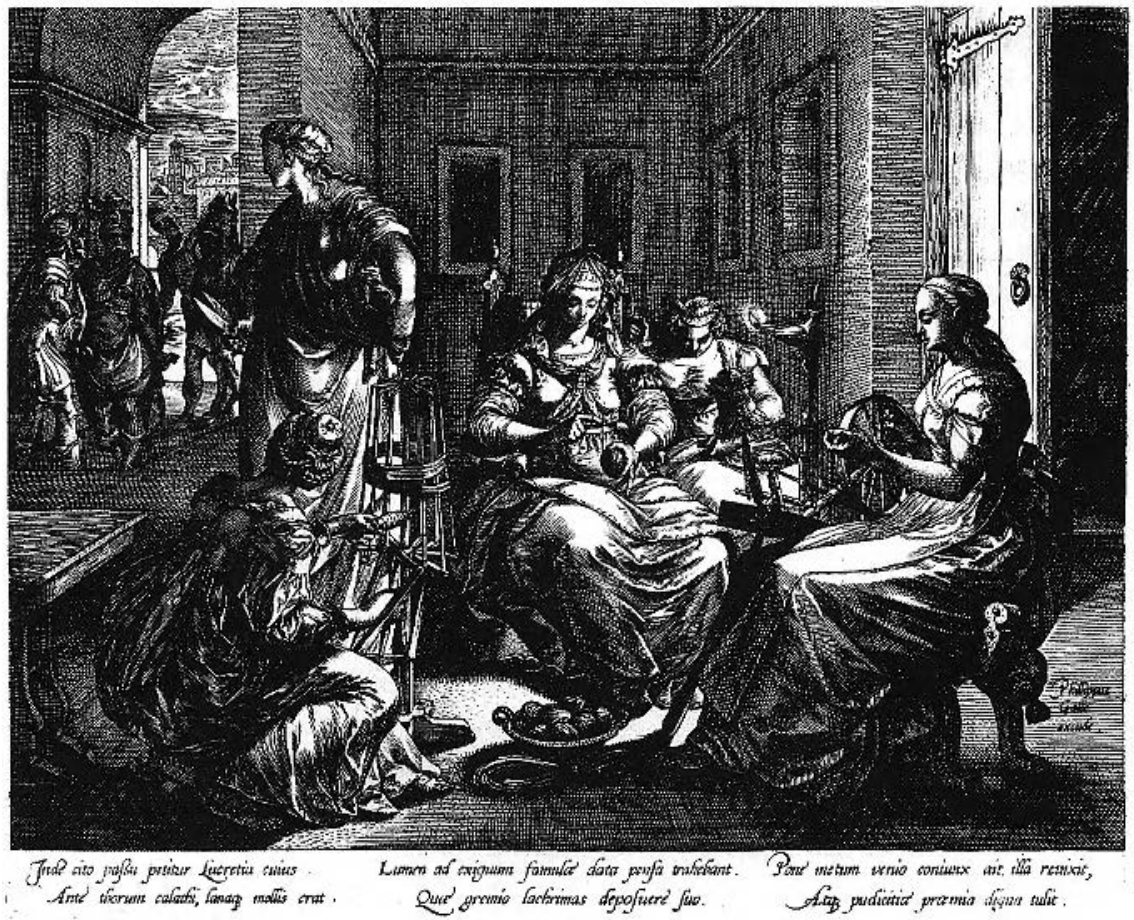

need to communicate "talkativeness." This fear was nurtured by the spinning chambers, a pre-industrial form of yarn production, but also a place for gatherings and festivities. Work and leisure mingled, and authorities watched these gatherings carefully. The earliest complaints about and restrictions on spinning chambers known in Hessen, Germany, date from the mid-sixteenth century. ${ }^{53}$ In the early Renaissance the spinning chamber became a symbol of the decline of moral standards attributed to the lower classes $^{54}$ and was depicted as a shelter of sin and lust, a hotbed of immorality. In Barthel Beham's woodcut A Spinning Chamber $(1524)^{55}$ the women are occupied with all sorts of amorous activities rather than working. The bad reputation of spinning as a professional activity was reinforced through the negative view of spinning chambers by authorities. ground is sewing. All the women express utmost sincerity in their actions. The full concentration on their domestic work symbolizes their rejection of all temptation, sexual or otherwise. In the mid-sixteenth century print by the engraver H. Cock, The Parable of the Wise and Foolish Virgins, based on a design by Pieter Bruegel, ${ }^{49}$ the Wise Virgins are occupied with the same activities as Lucretia and her maidens. In addition, one woman washes cloths in a big tub. In these prints, daily household chores symbolize virtuous behaviour. In both images, a burning candle signals night, underlining that the women resist all temptations through working, even at the dark time of seduction. The candle also refers to their praiseworthy industriousness, as with Luther's emphasis that a good wife's lantern does not go out at night. ${ }^{50}$

Bruegel and Goltzius were also concerned to stress that the women were silent. Talkativeness was a form of female behaviour which was widely inveighed against. The Malleus Maleficarum, the most influential book for witch-hunters, warns against women's "slippery tongues" and their incapability of keeping secrets, connecting it with their predisposition to witchcraft. ${ }^{51}$ In a commentary on the Sachsenspiegel, the author justifies women's exclusion from court and testimony with the fact that they chatter and gossip without understanding and that they are, moreover, very fickle. ${ }^{52}$ These sources reveal a steady fear of a "women's network" which men could not control and the attempt to prevent firm solidarity among women by pejoratively calling their
The connection of dutiful spinning with the rejection of sexual seduction, already the subject in Lucretia's story, becomes the focus in one of Israhel van Meckenem's Scenes of Daily Life (Fig. 3). Despite the title and Meckenem's "programmatic interest in the secular and commonplace," the artist is mainly concerned with matters of love, relationship and marriage. A courtier "dressed as some fifteenthcentury dandy with feathers and exotic turban" 56 confronts a young lady who is extremely busy with spinning. His sexual desire is symbolized by his dagger, the placement of which recalls an erect penis. The sexual notion is further reinforced by the placement of his hand at the height of his genitals. Whereas the women in the other three scenes seem to be more responsive to the attempts of seduction, the sincere and sober look of the lady, as well as her full concentration on her occupation, tell the onlooker that she will not succumb to the young man's desire. Above all, the iconography of spinning as almost uniquely considered a virtuous activity for women indicates her resistance. The prudish look of the cat towards the viewer also implies the chastity of her owner. The images discussed, as different as they are in style, nonetheless, share the important features of sincerity, silence and sobriety.

Coming back to van Heemskerck's image (Fig. 1), the woman's spinning represents her as dutiful and chaste, an outstanding example of praiseworthy womanhood, an image paralleled in the spinning wheel that is a decorous, costly jewel of the carpenter's art. Her chaste dress, the white cap 
Figure 3. Israhel van Meckenem, The Visit to the Spinner, ca. 1495-1503. Engraving, $161 \times$ $110 \mathrm{~mm}$. National Gallery of Art, Washington D.C.

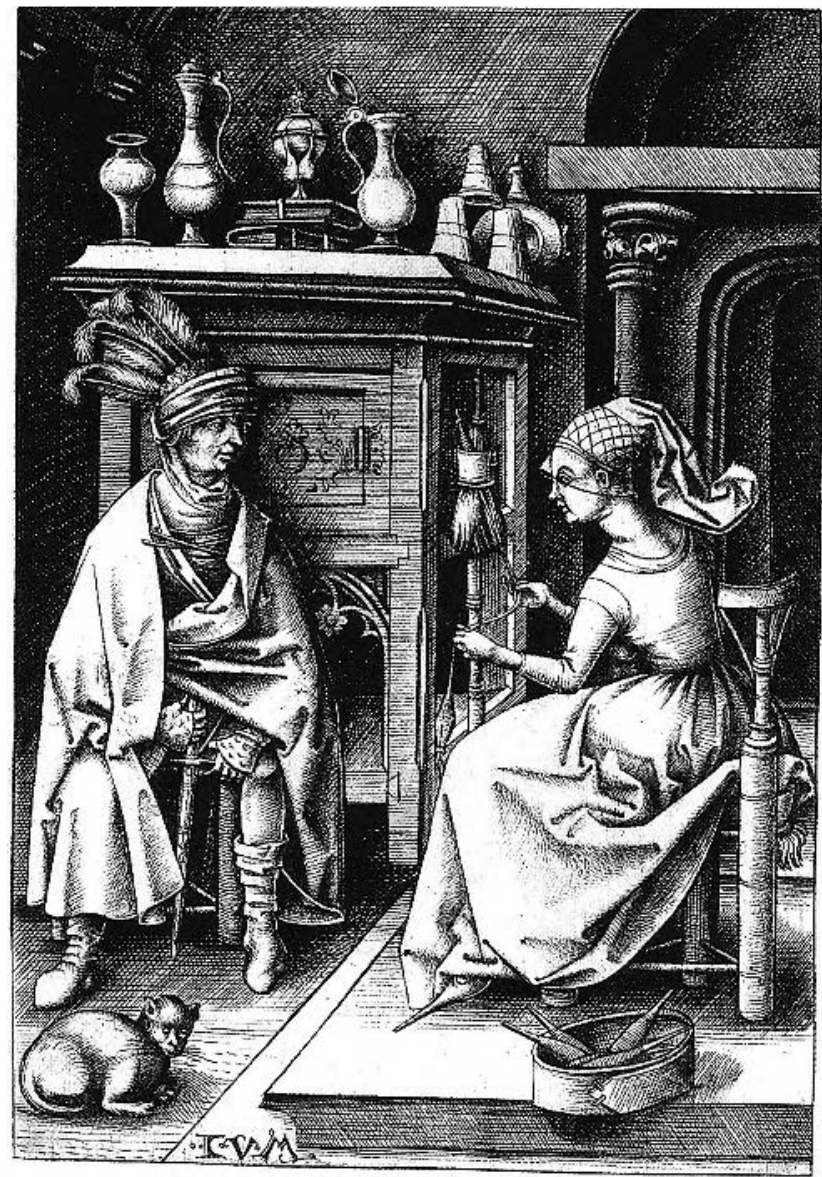

that covers her hair completely, her solemn facial expression and the spareness of the room surrounding her stress her qualities as a good, industrious and frugal housewife and outline her virtuous behaviour in life. Since she is a member of a wealthy household and obviously belongs to the well-situated burgher class, the activity of spinning is a symbol of her character, not of work itself. At the same time, the portrait also conveys a sense of self-confidence, as her gaze is direct and self-assured, although not bold. ${ }^{57}$ The reevaluation of women's contribution to family life and conjugal happiness is manifest in this painting. It becomes even more outspoken in Maerten van Heemskerck's double portrait of a man and a woman, traditionally identified as Anna Codde (Fig. 4) and Pieter Bicker (Fig. 5). ${ }^{58}$ The latter holds an open book with his left hand and a coin with his right hand, as attributes of his occupation. On the table are scattered tools necessary for bookkeeping. The mirror on the wall behind him might be an allegorical reference to Prudentia, a symbol for his insight into commercial affairs. ${ }^{59}$ His mood is sober and restrained, and his firm look indicates that he can master life, as well as business, with his intellectual and mathematical abilities. He represents the new type of self-assured businessman that emerged in the Renaissance. Working basically as an individual, he only co-operated with colleagues for major undertakings and transactions and competed with those merchants organized in the Hanseatic League. ${ }^{60}$

The emphasis on his profession, which was based on money-related transactions, became possible because the ancient ban upon usury gradually lost its force, and the charge of usury, although still invoked during the Renaissance, became a dead letter. ${ }^{61} \mathrm{~A}$ "middle-class value pattern" 62 formulated in the course of the fifteenth century focused on work and individual achievement. In 1525, Martin Luther stated that nobody dies from work, but rather from leading a life in idleness. According to Luther, it was the duty of a man to live by the "sweat of his brow," which for Luther was valid not only for physical professions but also for trade and business. ${ }^{63}$ The new work ethic allowed the burgher class to represent its status poignantly by referring to the professions of its members.

These new values soon found expression in portraiture. Hans Holbein's 1532 portrait of the Hanseatic merchant Georg Gisze of Danzig (Fig. 6) shows a design similar to that of Heemskerck's painting (Fig. 5). The young merchant stands behind a broad table that is covered with a costly oriental carpet and strewn with objects of his business pens, scissors, an inkpot, a round box with coins, a seal and a mechanical clock. The portrait signifies the honour, wealth and dignity of the sitter. A comparison with earlier depictions of wealthy merchants demonstrates that this display of business-related objects and earned money was an invention of the Renaissance. In Hans Memlinc's double portrait from c. $1480,{ }^{64}$ showing the wealthy Italian businessman Tommaso Portinari and his wife Maria Baroncelli, for example, nothing hints at Portinari's profession as the representative for the Medici family in Bruges. ${ }^{65}$

While Pieter Bicker is characterized as a bold and shrewd businessman (Fig. 5), his wife is depicted spinning (Fig. 4), again symbolic of the virtuous housewife. In contrast to Heemskerck's other image, however, Anna Codde seems to be lost in thought. This addresses another aspect of spinning: it was not only thought to be productive for the family, but also suitable for women because it gave them time to reflect on religious matters. ${ }^{66}$ In the Granatapfel, a book published for the edification of nuns in 1510, the title woodcut of the third part shows St Elizabeth of Thuringia spinning (Fig. 7). In a 1502 sermon in Strasbourg, the author of the book, Johann Geiler von Kaysersberg, explained that a woman should meditate on religious issues while spinning, much as St Elizabeth does. ${ }^{67}$ Piousness is no longer 
Figure 4. Maerten van Heemskerck, Portrait of a Woman (Anna Codde)), 1529. Panel, 86,3 x $66.4 \mathrm{~cm}$. Rijksmuseum, Amsterdam.

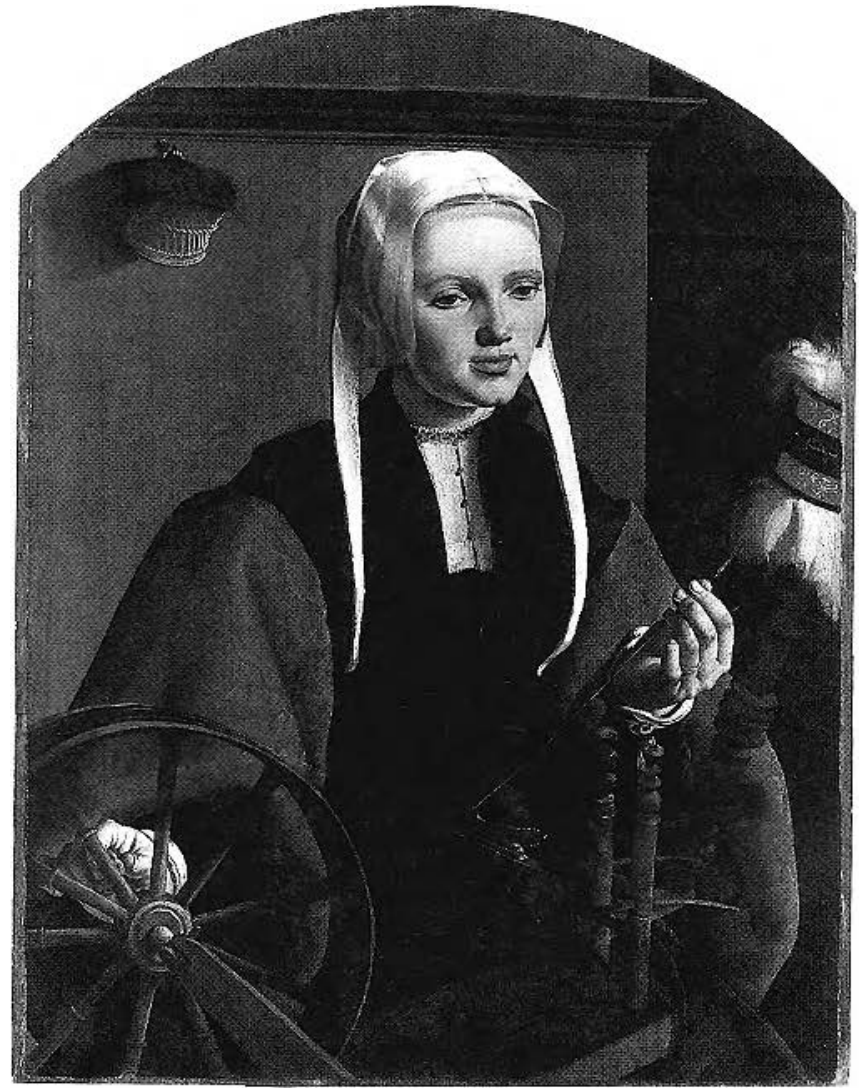

expressed through folded hands, as in the double portrait of the Portinari couple, but through work. Heemskerck's paintings might also be read as signs of affection between the sitters. The space is unified by the lighting that illuminates Anna from the right and Pieter from the left. The light source appears to be placed in the middle, between the two portraits. It indicates that they belong closely together. In addition, Anna Codde is placed on Pieter's right side, the side of honour. This might indicate her origin from a more important family, ${ }^{68}$ but perhaps it also signifies an appreciation of her contribution to the family. Yet, at the same time, the couple is clearly separated, one from the other. Pieter Bicker is firmly placed in the public realm of business and Anna Codde in the domestic realm of housewifery, representing the strict division of public and domestic life that was also part of the reformer's outlook. As the nuclear family gained hegemony as the preferred social unit, cultural ideologies of "woman" were constructed and reinforced by means of economic categories. Thus, Martin Luther ascribed the role of the breadwinner to the man and that of the housekeeper to the woman. ${ }^{69}$

This construction of roles, however, was only possible with the subordination of wives to their husbands. Thus, spinning found its place within the subject of the Power of
Figure 5. Maerten van Heemskerck, Portrait of a Man (Pieter Bicker?), 1529. Panel, 86,3 x 66,4 cm. Rijksmuseum, Amsterdam.

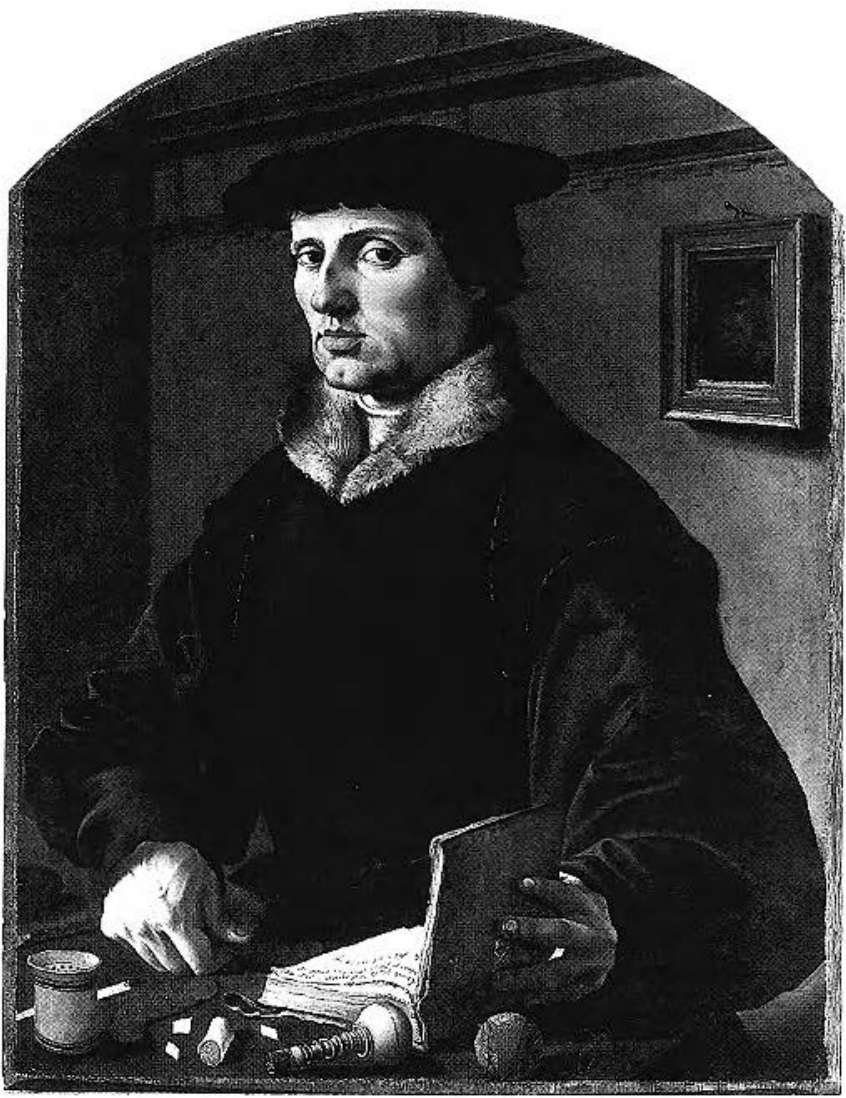

Woman, so popular in the late fifteenth and sixteenth centuries. The flood of renderings warning against women's wiles, which lead men to destruction, completely reversed the earlier medieval view of virtuous heroines and stressed the importance of male dominance over women. The implications of the depiction of Aristotle and Phyllis, for example, shifted from anti-Aristotelianism, pure and simple, to criticism of the power of women during the fourteenth and fifteenth centuries. ${ }^{70}$ Northern European images of rape also underwent a change in tone and content, later ones blaming the victim instead of condemning the rapist. ${ }^{71}$

In relation to men, domestic tasks were associated with inferiority. In Lucas Cranach's Hercules and Omphale (Fig. 8), ${ }^{72}$ the artist emphasizes the degradation and effeminization of the hero by showing him spinning. The white cap that the maidens put on his head also symbolizes his surrender to Omphale's servants, the closeness of the female figures suggesting that love caused the hero's downfall. ${ }^{73}$ He holds a thin, translucent thread between his outstretched hands, and his right arm is placed around a distaff. His gesture mirrors that of the maid behind him, holding a transparent veil. Hercules is trapped between veil and thread, the former identified with female sexuality, the latter with female occupations. Both symbolize the danger- 
Figure 6. Hans Holbein, Georg Gisze of Danzig, 1532. Panel, 96,3 ×85.7 cm. Gemäldegalerie, Berlin.

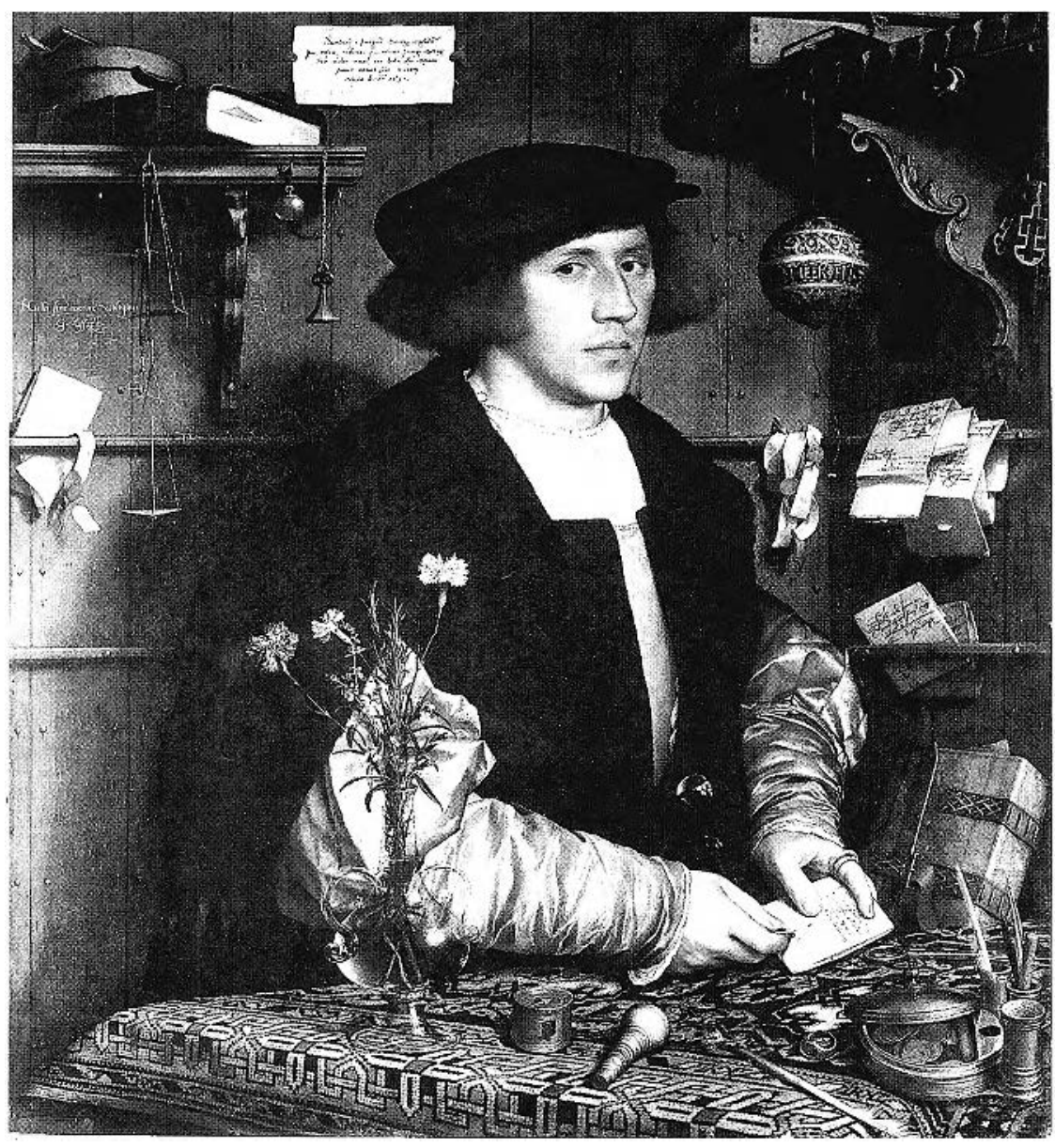

fashion suddenly changed, suggesting that masculinity was waging a new campaign for superiority. In contrast to fifteenthcentury clothing, which emphasized a slender, graceful physique, the new cuts favoured the breadth and mass of the male body. ${ }^{76}$ In the struggle to restrict women to the home, the different physical appearances of the sexes were also used as an argument. Martin Luther stated that a man is more intelligent than a woman because he has a broader thorax and small hips, whereas a woman has a small thorax, broad hips and a protruding bottom that destined her for sitting quietly at home, keeping the house and bearing children. ${ }^{77}$ Thereby, an appropriate attribute of womanhood - spinning comes to symbolize the most ridiculous and humiliating activity a man can do, and thus reveals contemporary attitudes towards women's tasks. Even the most virtuous woman could only be superior within the female sphere, but women remained inferior per se to men, in terms of the challenges they could confront. This attitude went so far as to stress, as Wolfgang did in 1533, that God invented so many good and necessary house-

ous web of female wiles in which, according to contemporary value schemes, a man could get caught.

In a later example of the subject, Bartholomaeus Spranger ${ }^{74}$ enhanced the allusion to sexual intercourse that is already part of Cranach's image. ${ }^{75}$ In his painting, Omphale and Hercules have exchanged clorhes, and Omphale's seductiveness is enhanced by the texture of the lion's fur and the rough wooden club, which contrasts with her soft skin. Presented as a nude seen from the back, she looks coquettishly over her shoulder towards the viewer, hardly covered by the lion's fur. Hercules, however, wears a silken dress held together by a jewelled buckle on the shoulder, holding a distaff in his left hand and a spindle in his right. The hero's female dress drastically underscores his unmanliness, effeminization and loss of reputation. His muscular, athletic body emphasizes his physical strength, in contrst to the feminine form of Omphale, and thus reinforces the erotic character of the composition, as well as the absurdity of the figures' exchanged costumes.

The costumes play an important role in achieving the specific meaning of the painting. Around 1500, German hold chores in order to rescue women from laziness and self-indulgence. ${ }^{78}$

To conclude, the imagery of spinning followed two paths. In contrast to earlier images, the work that wealthy Dutch women perform in Renaissance images is meant to dignify them (Fig. 1, 4). Yet, none of these images refer to paid labour. Spinning was only evaluated as a positive activity for women as long as it was not their profession. Professional spinners were usually identified with prostitutes. In his painting Lovers in a Tavern $(1570)^{79}$ Pieter Pietersz. shows a couple in the back room of a brothel. The young man slips his right hand into the woman's blouse; the woman puts her left hand onto his knee as a sign of consent, while she holds a distaff with her other hand. Here, spinning is used as a meraphor for selling oneself. In these images, the arts reflected the strong aversion against female participation in trade and business.

It was, thus, not by chance that spinners were chosen as a prominent target of these attacks, as they represented the majority of working women. Early Modern weaving techniques necessitated a large number of spinners, so that ap- 
Figure 7. Hans Baldung Grien, Saint Elizabeth Spinning, 1512. Woodcut, $175 \times 139 \mathrm{~mm}$. Augustiner-Museum, Freiburg im Breisgau.

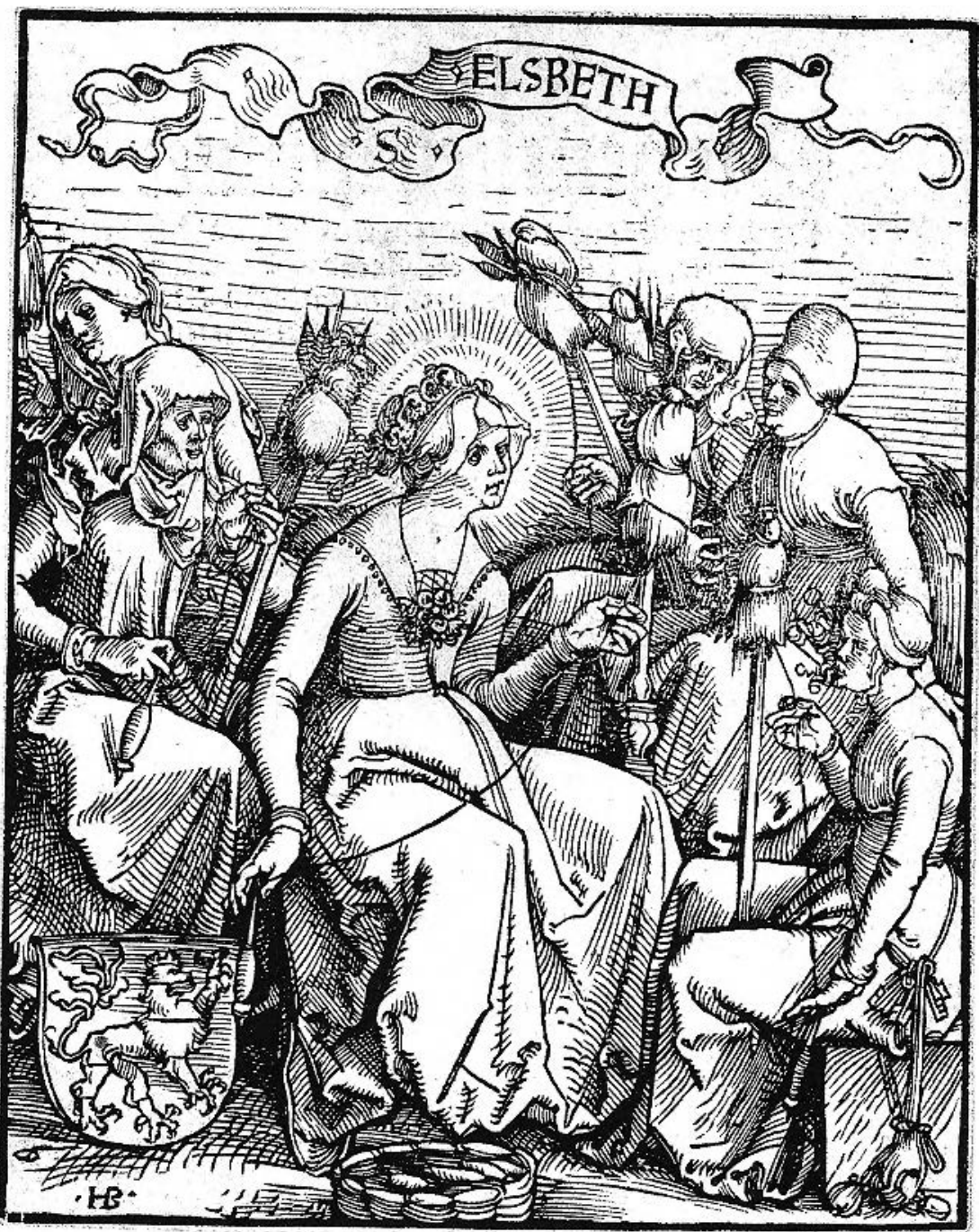

doing so in a prominent position. Yet, women working independently did exist in Frankfurt. Jost Amman did not depict a female tailor, although Frankfurt's statutes allowed independent female tailors to enter the guild. They could pass on their guild rights to their children and husbands. If a woman married after joining the guild, her husband could become a master without paying the normal entrance fee, even if he had not been trained as a tailor. These far-reaching rights indicated the vital role of female tailors within the city's guild. ${ }^{82}$ In Jost Amman's woodcut, however, all the tailors are male, their female colleagues replaced by the fine dresses that are hanging from the ceiling. The roles distributed to the sexes in Jost Amman's series clearly follow the norms of patriarchy: the productive role is reserved for men, while women occur only in the margins as clients or minor assistants. This distinction is especially well established in the woodcut of the mirror-maker in which a woman, part of a richly dressed couple, admires herself in one of the mirrors, a reference to female idleness that contrasts with the industriousness of the craftsmen.

The subjects of these art works raise the whole question of the audience for whom the images were designed and the intention behind them. As woodcuts, usually produced for the open market and sold

proximately five to ten thousand carders and spinners, most of them females who worked at home, lived in cities with a high number of weavers, such as Augsburg, Frankfurt and Ulm. ${ }^{80}$ Although even married women of the lower social strata relied on spinning for additional income, the sexualization of images of them working was used to discredit their work. The potential independence and increasing reputation that work could otherwise provide was eliminated by relegating professional spinning to the dishonourable occupations. Consequently, female craftsmen were hardly shown in more prestigious depictions of the trades.

In 1568, Hans Sachs published his book Eygentliche Beschreibung aller Stände aufErden, printed in Frankfurt. The first edition was illustrated with 114 woodcuts by Jost Amman. ${ }^{81}$ Ninety-eight of these represented professions organized in guilds, including the fine arts, but only the images of oil- and bell-making represent women actively working, and in front of the workshops or at fairs, were comparatively cheap, ${ }^{83}$ they found wide-spread distribution among the urban population. They helped to spread the ideas of humanists and reformers through the concrete, often exemplary and very populist rendering in this print medium. In contrast to woodcuts, paintings were more representative and expensive, were mainly purchased by the well-to-do burgher class, and thus reached a smaller audience. Mostly exhibited in the relatively private realm of the home, they nevertheless played an important role in the representation of the buyers among their class, establishing status and certain moral values as indispensable guidelines. In both cases, images served as a useful and powerful tool of propaganda:

Against this backdrop, the selection of certain facets of life and the exclusion of successful working women silenced the female voice. The fact that women were increasingly relegated to the margins of the labour force in the North is 
Figure 8. Lucas Cranach the Elder, Hercules and Omphale, 1532. Panel, $79 \times 116 \mathrm{~cm}$. Gemäldegalerie Berlin (missing since the Second World War).

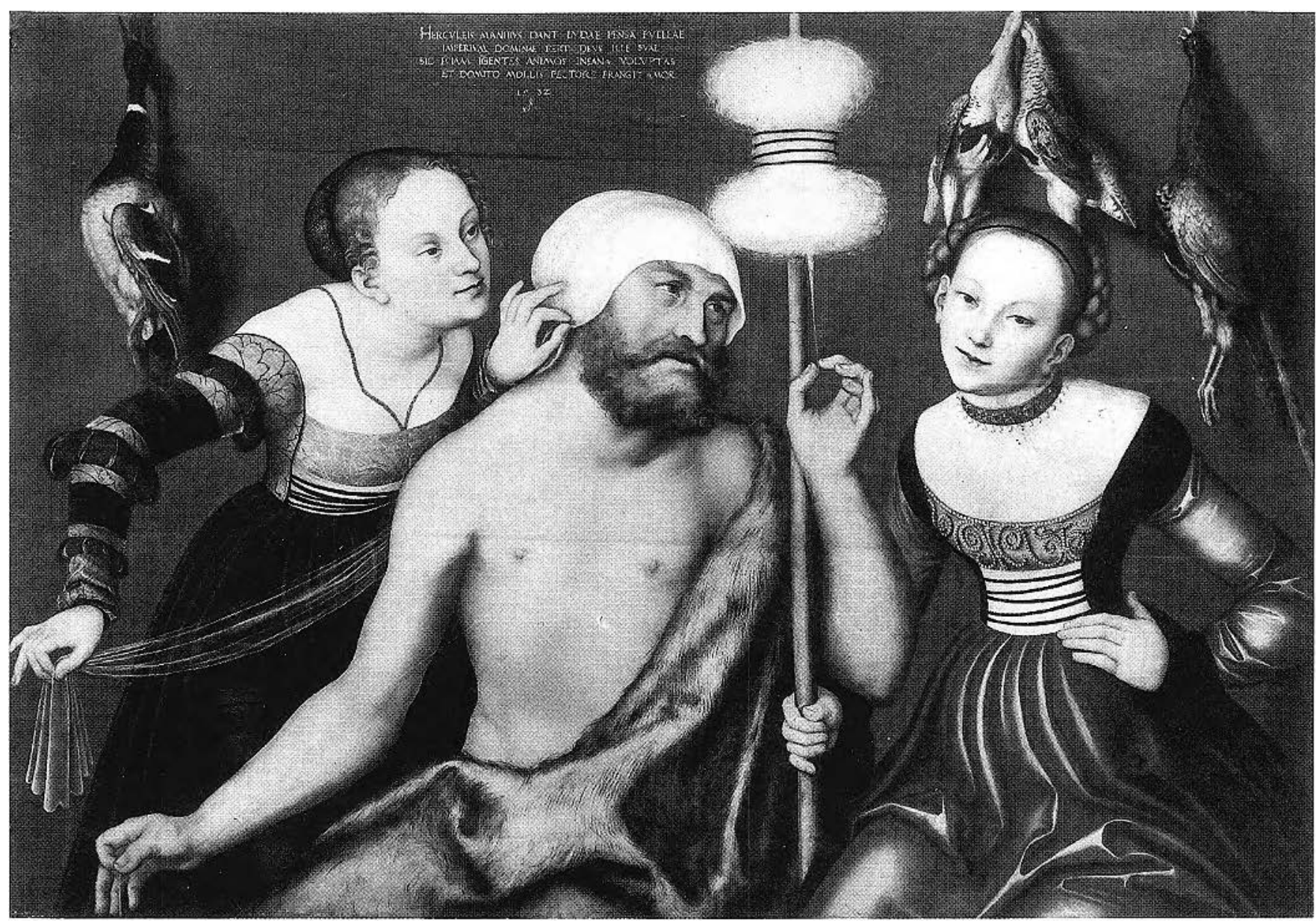

anticipated and reinforced by the visual material. Thereby, the imagery focused on the interests of the urban middle class, the patriciate, the town councils and the craft guilds. The poor, to whom the majority of female wage and home workers belonged, could not afford to concentrate solely on domestic matters. The denigrating association of professional spinning with prostitution appears to be an attempt not only to discredit women who performed this kind of labour, but also to distinguish the wealthier burghers from the lower strata of society. Spinning was not at all lucrative, hardly providing enough to support the worker, and it therefore became a metaphor for the lower classes, mostly for maids living in households, pieceworkers and day labourers. Due to the low wages, women were predominantly characterized as "poor" in city tax records; their labour became essentially proletarianized, and their economic security was minimal. ${ }^{84}$ Spinning as paid employment, either at home or in factories, was incompatible with the model of the virtuous housewife. At the same time, the depiction of spinning was also used to distinguish the wealthy burgher class from the aristocracy, where spinning, like any manual work, was regarded as inappropriate. Thus, authors emphasized that St Elizabeth proved her pious character and her willingness to make sacrifices for her religious beliefs in her readiness to spin wool and weave garments for a cloister, even though she was aristocratic by birth. ${ }^{85}$

The didactic character of the images becomes obvious considering the immense number of images of working women that are either sexualized or moralized. In this context, not only widely disseminated prints, but also paintings in the home, were thought to be effective means of influencing young girls. As Erasmus pointed out, a "picture speaks, albeit mute, and slowly but surely gains a hold on men's souls." 86 The portraits discussed above, therefore, not only served the purpose of demonstrating the status of the sitters and their moral integrity; the depiction of virtue and chastity as the highest goals in a woman's life, symbolized in the activity of spinning, can also be read as a device to direct the minds and consciousness of young daughters and to instill these characteristics in them as desirable. The division shown in the portraits is analogous to images found in the highly popular manuals on the right upbringing of 
children. In the manual, Regiment der jungen Kinder, published in 1473, Bartholomaeus Metlinger's title woodcut represents mother and daughter sitting side by side, occupied with spinning. ${ }^{87}$ Whereas the mother prepares her daughter for her future life as a married housewife, the father counts money and keeps record of it in an open book. The little boy on the floor is busy with reading, a symbol of learning, as well as of his future involvement in business and public life. ${ }^{88}$ The manuals also propagated the distribution of certain roles for the sexes.

The significance that the patriarchally structured family gained as the unit on which the state was based during the Renaissance might be explained in the context of the rise of absolutist territorial states, with their increasingly centralized governments. The reformers, as well as the authors of the "housefather" books, viewed the family as a system of organization that was analogous to the polity. ${ }^{89}$ Thus, Luther emphasized the importance of the correct upbringing of children, in order to produce useful, responsible members of the state, necessary for effective governing of the state. ${ }^{90}$ The importance of children's upbringing was emphasized throughout the literature of the time. ${ }^{91}$

Images of women spinning clearly referred to this propagated division, as no reference is made to paid labour. The existence of the French schools, however, indicates that wives of merchants actually helped their husbands in managing the mutual business, but references to this function are avoided. ${ }^{92}$ Examples of successful businesswomen and widows who continue to run the workshops of their dead spouses $^{93}$ are omitted, as they did not fit into the picture of the desired contribution of sex roles. Even in depictions of groups spinning, the focus is on chastity, not on domestic industry, as in the example of Lucretia. It can thus be said that female learning, business acumen and skill were present but kept hidden from art out of consideration of the social system. ${ }^{94}$

As mentioned above, spinning belonged among the lowest paid jobs, and spinners, while mostly working at home, remained isolated. They developed litcle work identity and did not organize themselves as a group. ${ }^{95}$ The denial of role models based on these social realities in the imagery heightened the isolation of women involved in domestic production and, together with the association with prostitution, fostered a loss of self-esteem, independence and economic power. Using the image of spinning mainly in metaphorical or symbolic ways, artists disguised existing economic and power relations and neglected the importance spinning had as extra employment to support families or single women.

A powerful means of lessening the importance of women was to trace their every action, their every characteristic, back to their sex. The number of sexualizing images of the Power of Women that grant women only their sexual attraction as their means of power is astonishing. Renaissance society viewed every woman as the infinite Eve, who has brought death and sin into the world and destroys men with her wiles. ${ }^{96}$ Moreover, witch-hunters claimed that "All witchcraft comes from carnal lust, which is in women insatiable."97 In the course of the witch-hunt, the argument became tautological and the rhetoric deadly for numerous women. The sexualizing and moralizing of almost all images of women was a valuable tactic in disguising the real object of struggle - the desired oppression of female authority and independence that they had achieved during the High Middle Ages. Apparently, the threat to the cultural, social and political power of men was not female sexuality, as most images attempt to convince the audience, but female skills, intellectual abilities and, above all, independence. Praising a woman's beauty or condemning her insatiable sexual appetite were two sides of the same coin. Both were methods of absorbing a woman's individuality in an abstraction of either platonic love or evil vice and to disguise her personality in metaphors and stereotypes designed as labels for women. ${ }^{98}$

The imagery only left women a choice between virtuous behaviour, which implied the acceptance of male dominance, or the life of a whore, not a real choice at all. The one-sided empowering of the male sex to the detriment of women was upheld by the often maintained and fancifully elaborated claim that it was based on natural conditions. Moreover, women were closely identified with nature, suggesting that women's behaviour springs from instinct rather than from reason. In Hans Baldung Grien's representations of witches' sabbaths, the witches have long, wild hair, the traditional attribute for witchcraft, and uninhibited movements. Their wildness was seen as an expression of forces that lie beyond reason, defying man's understanding and even more so his control. ${ }^{99}$ In the end, sexualizing and moralizing were means of diminishing the actual contribution of women to the economy and to family income, characterizing them as insignificant, of lower social status and of inferior moral standing.

Yet, the vehement warnings against female power dealt only on the surface with sexuality. On a deeper level, they addressed the necessity of permanent pressure in order to sustain male dominance. According to Luther, women want to rule by nature. In his opinion, the subordination of women under male dominance is harder for them to bear than the pain they suffer in giving birth. Yet, he saw this fate as the penalty for the Fall of Man, which was due to Eve. ${ }^{100}$ The misogyny that Renaissance images of women's wiles display so forcefully might be explained as a reaction 
to the resistance of women to accept the new role ascribed to them. Since this role was experienced as a guarantee in stabilizing new social structures and was significant for the organization of the state, much effort was put into the propaganda for these ideals.

1 Dagmar Schlapeit-Beck, "Frauenarbeit und der Stand der Technologie als Thema der Malerei. Das Motiv der spinnenden Frau," kritische berichte, II (1987), 31.

2 Schlapeit-Beck, "Frauenarbeit," 20.

3 Nathalie Kampen, Image and Status: Roman Working Women in Ostia (Berlin, 1981), 68.

4 Kampen, Image and Status, 96.

5 Kampen, Image and Status, 123.

6 J.P. Filedt Kok, W. Halsema-Kubes, and W.Th. Kloek, Kunst voor de beeldenstorm: Noordnederlandse kunst 1525-1580 (Amsterdam, 1986), 411.

7 Renee Pigeaud, "Woman as temptress: Urban Morality in the 15th century," Lene Dresen-Coenders, ed., Saints and She-Devils: Images of Women in the 15th and 16th centuries (London, 1987), $41 \mathrm{ff}$. Although the term is problematic for the early Renaissance period, it seems to be most suited to describe the emerging classes.

8 Pigeaud, "Temptress," 50.

9 Pigeaud, "Temptress," 44ff.

10 Pigeaud, "Temptress," 45.

11 Pigeaud, "Temprress," 42.

12 Kok, et al., beeldenstorm, 30 .

13 Kok, et al., beeldenstorm, 30.

14 Karina Kroj, Die Abhängigkeit der Frau in Eherechtsnormen des Mittelalters und der Neuzeit als Ausdruck eines gesellschaftlichen Leitbildes von Ehe und Familie: Zugleich eine Untersuchung zu der Realisierungschancen des zivilrechtlichen Gleichheitsgrundsatzes (Frankfurt, Bern, New York and Paris, 1988), 90f.

15 "If you find things going too well, take a wife;" Sebastian Franck, Sprichwörter, Schöne, Weise, Klugreden (Frankfurt, 1548), 144.

16 The humanist point of vicw was preceded by ideas spread by the reforming movement known as the Devotio moderna, which was especially widespread in Holland. Kroj, Abhängigkeit der Frau, 45, $104 \mathrm{ff}$; Steven Ozment, When Fathers Ruled: Family Life in Reformation Europe (Cambridge, Mass., and London 1983), Iff; Petry Bange and Grierje Dresen, and Jeanne Marie Noel, "'Who can find a virtuous woman?' Married and Unmarried Women at the Beginning of the Modern Time," DresenCoenders, ed., Saints and She-Devils, 20ff.

17 Bange, "Married and Unmarried Women," $20 \mathrm{ff}$.

18 Albrecht von Eyb, Ehebüchlein, Faksimile der Originalausgabe von Anton Koberger, Nürnberg 1472 (Wiesbaden, 1966), 81.
19 Martin Luther, "Eine Predigt vom Ehestande", Wittenberg, 1525, in D. Martin Luthers Werke, Kritische Gesamtausgabe (Weimar, 1921), XVII/I, 12ff; quoted below as WA = Weimarer Ausgabe.

20 Ozment, Fathers, 1.

21 Bange, "Married and Unmarried Women," 25.

22 An example is Caterina van Hermessen, Young Woman Playing the Virginal, 1548; illustrated in Ann Sutherland and Linda Nochlin, Women Artists: 1550-1950 (New York, 1989), 105.

23 Bange, "Married and Unmarried Women," 28.

24 Kroj, Abhängigkeit der Frau, 53ff.

25 Nathalie Kampen reaches this conclusion with regard to the lack of depictions of Roman female weavers; Kampen, Image and Status, 134.

26 In Cologne, for example, from 3 percent in the fourteenth century to 0.8 percent in the fifteenth and 0.2 percent in the sixteenth century; Kroj, Abhangigkeit der Frau, 56.

27 Helmut Wachendorf, Die wirtschaftliche Stellung der Frau in den deutschen Städten des späteren Mittelalters (Hamburg, 1934), $138 \mathrm{f}$.

28 Wachendorf, Wirtschaftliche Stellung der Frau, 21.

29 Kroj, Abhängigkeit der Frau, 56.

30 Whereas female doctors had a good reputation during the Middle Ages, they disappear from the statistics during the sixteenth century, when medicine became the subject of university teaching; Kroj, Abhängigkeit der Frau, 48.

31 Edith Ennen, Frauen im Mittelalter (Munich, 1984), $240 \mathrm{f}$.

32 Kroj, Abhangigkeit der Frau, 50.

33 Merry E. Wiesner, Working Women in Renaissance Germany (New Brunswick, 1986), 152ff.

34 Kroj, Abhängigkeit der Frau, $60 \mathrm{f}$.

35 Dora Schuster, Die Stellung der Frau in der Zunftverfassung (Berlin, 1927), e.g. documents of 1494 and 1688.

36 Originally written in Latin, the Sachsenspiegel was translated into Middle and High German, Dutch, Polish, Czech, Russian, Ukrainian, and back into Latin, and was the foundation of several other law texts; see Adalbert Erler and Ekkehard Kaufmann, eds., Handwörterbuch der Rechtsgeschichte (Berlin, 1990), 128ff.

37 Kroj, Abhängigkeit der Frau, 18ff.

38 Meaning that a woman who grants a man her body also gives him authorization over her property.

39 Kroj, Abhängigkeit der Frau, 33.

40 Kroj, Abhängigkeit der Frau, $117 \mathrm{ff}$.

41 The only difference was that permission for unmarried women could nor be withdrawn, whereas it was only seen as temporary for married women.

42 Ozment, Fathers, 13.

43 WA, I, no. 1229, 611, translated by author.

44 Erasmus, Colloquia Familiaria: Vertraute Gespräche, trans. and ed., Werner Welzig (Darmstadt 1967), 153ff, 177, translated by author. 
45 Sebastian Brant, "Marrying for the Sake of Goods," The Ship of Fools, trans. Edwin H. Lcydel (New York, 1944), $182 \mathrm{f}$.

46 Illustrated in Jacques Lavallcye, Pieter Bruegel the Elder and Lucas van Leyden: The Complete Engravings, Etchings and Woodcuts (London, 1969), no. 187.

47 Jean Pierrc Bryn, "Vrocgge portretten van Maerten van Heemskerck," Bulletin van het Rijksmuseum, II (1955), 31.

48 Schlapeit-Beck, "Frauenarbeit," 21.

49 Illustrated in Rene von Bastelaer, Les Estampes de Pieter Bruegel L'Ancien (Bruxelles, 1908), no. 123

50) WA, no. $4783,500$.

51 Jakob Sprenger and Hcinrich Institoris, Der Hexenhammer: Malleus Maleficarum, trans. J.W.R. Schmidt (Munich, 1982), 98.

52 Hieronimus Christoph Meckbach, Commentar über den Sachsenspiegel, 2nd ed., (Wcimar, 1789), 588f.

53 Uwe Henkhaus, Das Treibhaus der Unsittlichkeit: Lieder, Bilder und Geschichte(n) aus der hessischen Spinnstube (Marburg, 1991), 134.

54 Schlapeit-Beck, "Frauenarbeit," 23.

55 Illustrated in Max Gcisberg, The German Single-Leaf Woodcut: 1500-1550 (Ncw York. 1974), 133.

56 James Snyder, Northern Renaissance Art: Painting, Sculpture, The Craphic Arts from 1350 to 1575 (New York, 1985), 291f.

57 John Walker and Alan Rosenbaum, Old Masters Paintings from the Collection Baron Thyssen-Bornemisza (Washington, 1979), 112.

58 Some scholars doube the traditional identification of the sitters: sec Kok, et al., beeldenstorm, 194.

5) Kok, et al., beeldenstorm, 194.

6) F.R.Chamberlin, Everyday I.ife in Renaissance Times (I ondon and New York), 76.

61 Chamberlin, Everyday Life, $63 \mathrm{ff}$.

62 Pigeaud, "Temperess," 41.

63 WA, XVII/I, 22f.

64 Snyder, Northern Renaissance, 186; illustrated there, fig. 178, 179.

65 Snyder, Northern Renaissance, 480.

66 Elizabcth of Thuringia, $1207-1231$, was the landgravine of Thuringia and daughter of King Andreas II. of Hungary.

67 Johann Geiler von Kaysersberg, Buch Granatapfel (Augsburg, 1510), Stadtarchiv Freiburg, cited in Thomas Schwarz, "Aus dem Bücherschrank Freiburger Frauenklöster: Frühdrucke der 'Alträter' und des 'Granatapfels'," Zu Dïrers Zeiten, Druckgraphik des 15. und 16. Jahrhunderts aus dem Augustinermuseum Freiburg, ed., Sybillc Bock (Freiburg, 1991), 43.

68 Kok, beeldenstorm, 194.

$69 \mathrm{WA}, \mathrm{XVII} / \mathrm{I}, 23 \mathrm{f}$.

70) Jane Campell Hutchinson, "Ihe Houscbook Master and the Folly of the Wisc Man," Art Bulletin, XLVIII (March 1966), 75.
71 Dianc Wolfthal, "'A Hue and a Cry': Medieval Rape Imagery and Its 'Iransformation," Art Bulletin, LXXV (March 1993), 57.

72 Cranach's design is unusual, as it docs not show Hercules in the company of Omphale herself but surrounded by her maidens. No images of the subject are known in the North before Cranach's time, but it later became a popular subject for Renaissance painters. Cranach himself painted four versions; see Dieter Koepplin and Tilman Falk, Lukas Cranach: Gemälde, Zeichnungen, Druckgraphik (Basel and Stuttgart, 1976), II, $574 \mathrm{ff}$.

73 This interpretation is supported by the inscription of the painting: "Hcrculeis manibus dant Lydae pensa puellae/ Imperium dominac fert deus ille suae/ Sic capit ingentes animos damnosa voluptas/ Fatiaque enervat pectora mollis armor" (The Lydian maidens assign work [pensa: day's work of a wool spinner] to the hands of Hercules/ The power of his mistress endures that divine/ Like this, pernicious carnal lust overcomes powerful minds/ And even the most capable natures are weakened by soft love).

74 Bartholomaeus Spranger, Hercules and Omphale, 1590s, illustrated in Prag um 1600: Kunst und Kultur am Hofe Rudolfs II., exhibition catalogue (Freren, 1988), no. 44.

75 Michael Henning, Die Tafelbilder des Bartholomäus Spranger (1546-1611): Höfische Malerei zwischen 'Manierismus' und 'Barock' (Essen, 1987), 60ff.

76 Alan Shcsack and James H. Morrow, eds., Hans Baldung Grien: Prints and Drawings (Washington, 1981), 20.

77 WA, I, no. 55, 19.

78 Ozment, Fathers, 69.

79 Illustrated in Kok, et al., beeldenstorm, no. $301 \mathrm{a}$.

80 Merry E. Wiesner, "Spinsters and Scamstresses: Women in Cloth and Clothing Producrion," Rewriting the Renaissance: The Discourses of Sexual Difference in Early Modern Europe, eds., Margaret W. Ferguson, Maureen Quilligan and Nancy J. Vickers (Chicago, 1986), 193ff.

81 Illustrated in Georg Hirth, Kulturgeschichtliches Bilderbuch aus drei Jahrhunderten (Leipzig and Munich, 1882), III, nos. 1157 1268, 1269-1282.

82 Wiesncr, Working Women, $173 \mathrm{f}$.

83 Albrecht Dürer, for example, organized the distribution of his woodcuts himself and sent his wife to the fair in Frankfurt to market them; see Sibylle Bock, "Druckgraphik zu Dürers Zeit," in Bock, ed., Zu Diirers Zeiten, 12.

84 Wachendorf, Wirtschaftiche Stellung der Frau, 147.

85 Anonymous fourteenth-century poet, Das Leben der Heiligen Elizabeth, trans. and ed. Manfred Lemmer (Berlin, 1981), 44.

86 Erasmus, Institutio Matrimonii Cristiani (1526), cited in Ellen Muller and Jeanne Marie Noel, "Humanist views on Art and Morality," in Dresen-Coenders, ed., Saints and She-Devils, 130.

87 Illustrated in Wiesencr, Working Women, XIV. 
88 Günter Zainer, Regiment der jungen Kinder (Augsburg, 1473).

89 Ernst Ullmann, ed., Von der Macht der Bilder: Beiträge des C.I.H.A.-Kollogiums 'Kunst und Reformation' (Leipzig, 1983), $150 f$.

90 WA, XXX/II

91 Sebastian Brant, "Of the teaching of Children," Ship of Fools, $72 \mathrm{ff}$.

92 Ozment mentions, for examplc, the wife of a carpenter in Cologne; see Ozment, Fathers, 13.

93 Ozment, Fathers, 13.

94 Kampen, Image and Status, 135.
95 Wiesner, Working Women, $184 \mathrm{f}$.

96 Anonymous, Davids Eebruch: Mordt Straff und Buss (Ulm, 1534); Ozment, Fathers, 206.

97 Sprenger and Institoris, Hexenhammer, 106.

98 On the topic of silencing women by praising their beauty, see Mary D. Garrard, "Leonardo da Vinci: Femalc Portraits, Female Nature," The Expanding Discourse, eds., Norma Broude and Mary D. Garrard (New York, 1992).

99 Charles W. Talbot, "Baldung and the Femalc Nude," in Morrow and Shestack, eds., Hans Baldung Grien, 19-37.

100 WA, XVII/I, 26. 